\title{
Tetragenococcus muriaticus sp. nov., a New Moderately Halophilic Lactic Acid Bacterium Isolated from Fermented Squid Liver Sauce
}

\author{
MASATAKA SATOMI, BON KIMURA, MICHIKO MIZOI, TSUNEO SATO, \\ AND TATEO FUJII* \\ Department of Food Science and Technology, Tokyo University of \\ Fisheries, 4-5-7 Konan, Minato-ku, Tokyo 108, Japan
}

\begin{abstract}
A total of 11 strains of moderately halophilic histamine-producing bacteria isolated from fermented squid liver sauce were studied phenotypically, genotypically, and phylogenetically. These strains are considered members of the genus Tetragenococcus based on their physiological, morphological, and chemotaxonomic characteristics. A 16S rRNA gene sequence analysis showed that these strains clustered with, but were separate from, Tetragenococcus halophilus. The results of DNA-DNA hybridization experiments indicated that the new isolates represent a new Tetragenococcus species, for which we propose the name Tetragenococcus muriaticus; strain X-1 (= JCM 10006) is the type strain of this species.
\end{abstract}

Pediococcus halophilus was described as a halophilic lactic acid bacterium which requires sodium chloride $(\mathrm{NaCl})$ for growth and is tolerant of a high $\mathrm{NaCl}$ concentration (more than 18\%). According to Bergey's Manual of Systematic Bacteriology (6), tetrad cocci which are tolerant of $18 \% \mathrm{NaCl}$ are members of $P$. halophilus. Recently, however, Collins et al. (4) reported that $P$. halophilus is phylogenetically more closely related to enterococci and lactobacilli than to pediococci on the basis of $16 \mathrm{~S} 16 \mathrm{~S}$ rRNA sequence data, and thus they proposed that $P$. halophilus should be reclassified in a new genus, the genus Tetragenococcus, with Tetragenococcus halophilus as the single species recognized in the genus (2).

Previous workers have isolated large numbers of T. halophilus as the predominant bacteria $(7,8)$ from Shottsuru, a Japanese local traditional fermented fish sauce, which contains more than $25 \% \mathrm{NaCl}$. In this study, we isolated histamineproducing lactic acid bacteria from Shottsuru-like squid liver sauce. Eleven strains were designated strains $\mathrm{X}-1^{\mathrm{T}}$ to $\mathrm{X}-11$ and were different from authentic $T$. halophilus strains in the following characteristics: production of histamine, lack of L-arabinose fermentation, growth at $40^{\circ} \mathrm{C}$, and $16 \mathrm{~S}$ rRNA gene (rDNA) sequence. To precisely identify and phylogenetically place the new isolates, phenotypic characterization, analysis of fatty acid compositions, $16 \mathrm{~S}$ rDNA sequencing, and DNADNA hybridization were performed. On the basis of our results we propose that our isolates should be placed in a new species, Tetragenococcus muriaticus.

\section{MATERIALS AND METHODS}

Bacterial strains and growth conditions. A total of 11 strains $\left(\mathrm{X}-1^{\mathrm{T}}\right.$ to $\left.\mathrm{X}-11\right)$ were isolated from squid liver sauce, a Japanese local traditional fermented seafood. These strains were maintained on stab cultures in $10 \% \mathrm{NaCl}-\mathrm{GYP}$ agar (10), which was supplemented with $10 \%$ sodium chloride, $1 \%$ magnesium sulfate, $0.1 \%$ potassium chloride, $0.5 \%$ calcium carbonate, and $0.3 \%$ agar. The $\mathrm{pH}$ was adjusted to 7.0 with $1.0 \mathrm{~N} \mathrm{NaOH}$. The cultures were incubated for about 2 days at $30^{\circ} \mathrm{C}$. The strains were stored at $4^{\circ} \mathrm{C}$ and were transferred to fresh medium every third month. Unless indicated otherwise, the inocula used for phenotypic tests were prepared from 48 - to 60-h-old cultures in $10 \% \mathrm{NaCl}-\mathrm{GYP}$ broth and incubated at $30^{\circ} \mathrm{C}$

Morphology. Cell morphology was observed by using scanning electron microscopy (SEM). For SEM, cells were fixed for $2 \mathrm{~h}$ in $2 \%$ glutaraldehyde, dehydrated with increasing concentrations of ethanol and isoamyl acetate, and

* Corresponding author. Phone: 81-3-5463 0602. Fax: 81-3-5463 0602. sputter coated with gold. Gram staining was studied by a modified Hucker procedure (10). Motility was observed by diffusion of colonies in $10 \% \mathrm{NaCl}-$ GYP semisolid agar and observation by phase-contrast microscopy.

Physiological and biochemical characteristics. Cell wall peptidoglycan contents, catalase activity, the lactate isomer, gas production, arginine hydrolysis, and sugar fermentation were determined by standard procedures (10). Histamine production was studied by a previously described method (14). All other phenotypic tests were performed in accordance with the standard protocols (21).

Fatty acid composition. Whole-cell lipids were extracted by the methods of Bligh and Dyer (3). The extracted lipids were converted to fatty acid methyl esters by the American Oil Chemists' Society methods (1). The fatty acid methyl esters were analyzed with a model GC15A gas-liquid chromatograph (Shimadzu, Kyoto, Japan) equipped with a flame ionization detector and a polar capillary column (Hi-cap CBP20) (Shimadzu). The carrier gas was He; the linear velocity was $20 \mathrm{~cm} / \mathrm{s}$; the column split ratio was $50: 1$; the injection port temperature was $250^{\circ} \mathrm{C}$; and the detection port temperature was $270^{\circ} \mathrm{C}$. The temperature profile of the column oven included a $4-\mathrm{min}$ isotherm at $150^{\circ} \mathrm{C}$ and subsequent programmed temperature increases (the temperature was increased at a rate of $4^{\circ} \mathrm{C} / \mathrm{min}$ to $250^{\circ} \mathrm{C}$ ). The bacterial acid methyl ester CP MIX (Supelco, Inc., Bellefonte, $\mathrm{Pa}$.) was used as a standard for identification of the fatty acid methyl esters.

DNA preparation. Cells were suspended in Tris-EDTA buffer $(\mathrm{pH} \mathrm{8.0)}$ and treated with lysozyme (final concentration, $2 \mathrm{mg} / \mathrm{ml}$ ) and sodium dodecyl sulfate (final concentration, $0.5 \%$ ) for lysis. Chromosomal DNA was purified by standard procedures (13), except that the final steps of the procedure were modified as follows: RNase treatment and ethanol precipitation were performed twice.

DNA base composition and DNA-DNA homology. The DNA base composition (guanine-plus-cytosine $[\mathrm{G}+\mathrm{C}]$ content) was determined by the high-performance liquid chromatography methods of Tamaoka and Komagata (16). DNA-DNA homology was studied by microplate hybridization methods (5) with photobiotin labeling and colorimetric detection, using 1,2-phenylenediamine (Sigma Chemical Co., St. Louis, Mo.) as the substrate and streptavidine-peroxidase conjugate (Boehringer, Mannheim, Germany) as the colorimetric enzyme.

Amplification of $16 \mathrm{~S}$ rDNA and restriction fragment length polymorphism (RFLP) analysis. 16S rDNA amplification was performed by a PCR method (15).

The PCR products were digested with restriction enzymes $A l u \mathrm{I}$ and $M b o \mathrm{I}$ (Takara Shuzou Co., Shiga, Japan), and fragments were analyzed by $6 \%$ polyacrylamide gel electrophoresis; then the gels were stained with ethidium bromide.

$16 S$ rDNA sequencing and phylogenetic analysis. The amplified DNA fragments were purified by $1.0 \%$ agarose gel (Nippon Gene, Toyama, Japan) electrophoresis and were recovered by ultrafiltration by using a filtration tube ( $\mathrm{Su}-$ prec-01; Takara). Purified PCR products were sequenced by using a Taq DyeDeoxy terminator cycle sequencing kit (Applied Biosystems, Foster City, Calif.) as directed by the manufacturer, and reaction mixtures were analyzed with an Applied Biosystems model 373A sequencer. Sequences were determined from overlapping sequence data by using the DNASIS computer program (Takara). Nucleotide substitution rates ( $K_{\text {nuc }}$ values) $(9)$ were determined, and a phylogenetic tree was constructed by the neighbor-joining method (12) by using the Clustal W program (17). Alignment gaps and unidentified base positions were not taken into consideration for the calculations. The robustness of the topologies was evaluated by a bootstrap analysis through 1,000 bootstrap replications.

Nucleotide sequence accession numbers. The $16 \mathrm{~S}$ rDNA sequences of strains $\mathrm{X}-1^{\mathrm{T}}$ and IAM $1676^{\mathrm{T}}$ have been deposited in the DDBJ (DNA Data Bank of 
TABLE 1. Designations and/or accession numbers of the lactic acid-producing bacteria analyzed in this study

\begin{tabular}{llc}
\hline \multicolumn{1}{c}{ Species } & \multicolumn{1}{c}{ Strains $^{a}$} & Accession no \\
\hline Tetragenococcus halophilus & IAM 1673 & \\
Tetragenococcus halophilus & IAM 1676 & \\
Tetragenococcus halophilus & IAM 1678 & D88668 \\
Tetragenococcus halophilus & IAM 1681 & \\
Tetragenococcus muriaticus & X-1 $1^{\mathrm{T}}\left(=\mathrm{JCM} 10006^{\mathrm{T}}\right)$ & $\mathrm{D} 88824$ \\
Tetragenococcus muriaticus & $\mathrm{X}-2(=\mathrm{JCM} 10007)$ & \\
Enterococcus cecorum & & $\mathrm{X} 54290$ \\
Enterococcus columbae & & $\mathrm{X} 56422$ \\
Enterococcus saccharolyticus & & $\mathrm{U} 30391$ \\
Enterococcus sulfureus & & $\mathrm{X} 55133$ \\
Vagococcus fluvialis & & $\mathrm{X} 54258$ \\
Vagococcus salmoninarum & & $\mathrm{X} 54272$ \\
Carnobacterium alterfunditum & & $\mathrm{L} 08623$ \\
Carnobacterium divergens & & $\mathrm{X} 54270$ \\
Carnobacterium funditum & & $\mathrm{S} 86170$ \\
Carnobacterium gallinarum & & $\mathrm{X} 54269$ \\
Aerococcus urinae & $\mathrm{M} 77819$ \\
Pediococcus damnosus & & $\mathrm{D} 87678$ \\
Lactococcus lactis & $\mathrm{X} 54260$ \\
\hline
\end{tabular}

${ }^{a}$ IAM, The Institute of Applied Microbiology (Institute of Molecular and Cellular Biosciences, The University of Tokyo, Bunkyo-ku, Tokyo, Japan); JCM, The Japan Collection of Microorganisms (The Institute of Physical and Chemical Research, Wako, Saitama, Japan).

Japan) database under accession no. D88824 and D88668, respectively. The accession numbers of the sequences used as reference sequences for the phylogenetic tree are shown in Table 1.

\section{RESULTS}

Morphology and cultural characteristics. The cells of all of the T. halophilus-like strains which were isolated from fermented squid liver sauce were gram-positive, non-spore-forming, nonmotile, tetrad cocci, and the majority occurred singly or in pairs at the early or mid-log phase. The cell diameter was 0.5 to $0.8 \mu \mathrm{m}$ as determined by SEM (Fig. 1). Colonies on $10 \%$ $\mathrm{NaCl}-\mathrm{GYP}$ agar plates after $60 \mathrm{~h}$ of incubation at $25^{\circ} \mathrm{C}$ were entire, smooth, white, and approximately 1.0 to $1.5 \mathrm{~mm}$ in diameter.

Physiological and biochemical characteristics. A summary of the phenotypic characteristics used to differentiate between the new isolates and T. halophilus is shown in Table 2. All of the strains were catalase negative and exhibited homogeneous fermentation, producing L-lactic acid as the sole metabolic

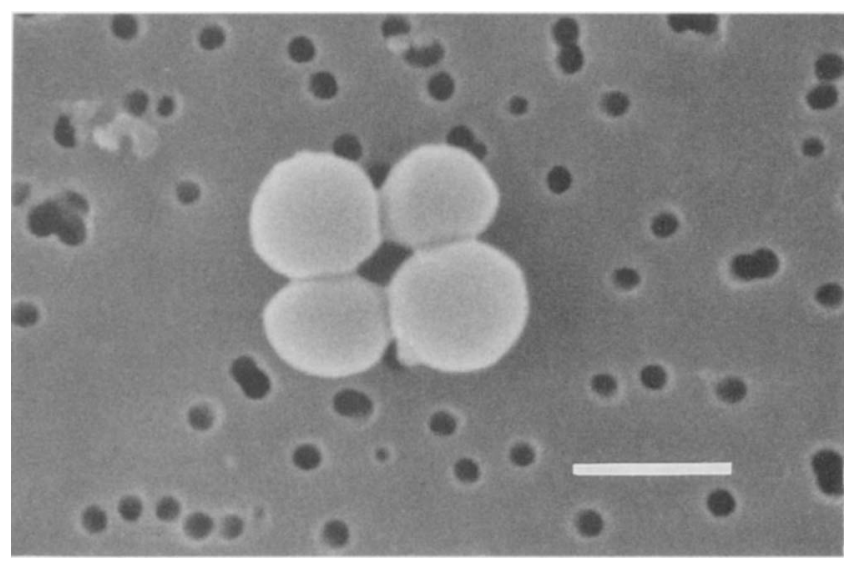

FIG. 1. Scanning electron micrograph of strain $X-1^{\mathrm{T}}$ cells. Bar $=1 \mu \mathrm{m}$.
TABLE 2. Characteristics which differentiate the new isolates and $T$. halophilus ${ }^{a}$

\begin{tabular}{lcc}
\hline \multicolumn{1}{c}{ Characteristic } & $\begin{array}{c}\text { New isolates } \\
\text { X-1 }\end{array}$ & T. halophilus \\
& to $^{\mathrm{T}}$-11 & - \\
\hline Histamine production & $+^{c}$ & - \\
Growth at $40^{\circ} \mathrm{C}$ & + & + \\
Acid production from: & - & + \\
L-Arabinose & - & - \\
Sucrose & + & \\
Mannitol & + & \\
\hline
\end{tabular}

${ }^{a}$ All of the strains were gram-positive cocci that did not form spores, were nonmotile, halophilic, facultatively anaerobic, and homofermentative, and produced L-lactic acid; the peptidoglycan type was Lys-D-Asp, and the G+C contents were 34 to $36 \mathrm{~mol} \%$. All of the strains grew in the presence of $18 \% \mathrm{NaCl}$ and produced acid from D-ribose, fructose, and trehalose. All of the strains were negative for catalase and oxidase activities, hydrolysis of arginine, nitrate reduc-

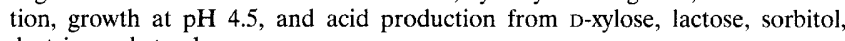
dextrin, and starch.

${ }^{b}$ Data from reference 6.

${ }^{c}+$, positive reaction; - , negative reaction.

product from D-glucose. They did not hydrolyze arginine or ferment L-arabinose. All of the strains produced histamine from L-histidine. The cell wall peptide contained Lys-D-Asp. The new strains were able to grow at $40^{\circ} \mathrm{C}$ but not at 10 and $45^{\circ} \mathrm{C}$. Optimal growth occurred at temperatures between 25 and $30^{\circ} \mathrm{C}$. All of the strains grew at $\mathrm{pH} 8.5$ but failed to grow at $\mathrm{pH}$ 4.2. The optimal $\mathrm{pH}$ was between 7.5 and 8.0. All of the strains were able to grow in the presence of wide ranges of $\mathrm{NaCl}$ concentration (1 to $25 \%$ ) and required $\mathrm{Na}^{+}$for growth. The optimal $\mathrm{NaCl}$ concentration was about 7 to $10 \%$. The $\mathrm{G}+\mathrm{C}$ content of new isolates $\mathrm{X}-1^{\mathrm{T}}$ and $\mathrm{X}-2$ was $36.5 \mathrm{~mol} \%$.

Fatty acid composition. The fatty acid profiles of new isolates $\mathrm{X}-1^{\mathrm{T}}$ and $\mathrm{X}-2$ and $T$. halophilus IAM $1676^{\mathrm{T}}$ (used as a reference strain) are shown in Table 3 . The major fatty acids of new isolates were 14:0, 16:0,16:1(n-9), 18:0, 18:1(n-11,n-9), $18: 2$, and $\Delta 19: 0($ cis 11,12$)$. The results of the cellular fatty acid analysis confirmed that new isolates $\mathrm{X}-1^{\mathrm{T}}$ and $\mathrm{X}-2$ and $T$. halophilus IAM $1676^{\mathrm{T}}$ had similar profiles in general, but the new isolates differed from IAM $1676^{\mathrm{T}}$ by their lower levels of $\Delta 19: 0($ cis 9,10$)$.

16S rDNA sequence comparisons. The results of the PCR RFLP analysis of the $16 \mathrm{~S}$ rDNA are shown in Fig. 2. A com-

TABLE 3. Fatty acid compositions of new isolates $\mathrm{X}-1^{\mathrm{T}}$ and $\mathrm{X}-2$ and $T$. halophilus

\begin{tabular}{lccc}
\hline \multirow{2}{*}{ Fatty acid } & \multicolumn{3}{c}{$\%$ in: } \\
\cline { 2 - 4 } & Strain X-1 & Strain X-2 & $\begin{array}{c}\text { T. halophilus } \\
\text { IAM } 1676^{\mathrm{T}}\end{array}$ \\
\hline $14: 0$ & 6.8 & 6.9 & 4.8 \\
$14: 1$ & ${ }^{a}$ & - & 0.8 \\
$15: 0$ & 1.0 & $\operatorname{tr}$ & 0.95 \\
$16: 0$ & 22.6 & 25.0 & 28.0 \\
$16: 1$ & 9.2 & 15.3 & 7.0 \\
$17: 0$ & $\operatorname{tr}$ & 1.9 & $\operatorname{tr}$ \\
$\Delta 17: 0$ & 1.1 & $\operatorname{tr}$ & 0.85 \\
$18: 0$ & 8.5 & 8.5 & 7.3 \\
$18: 1$ (n-11) & 23.6 & 26.2 & 12.6 \\
$18: 1$ (n-9) & 8.3 & 13.3 & 13.7 \\
$18: 2$ & 8.5 & 2.9 & 1.2 \\
$\Delta 19: 0($ cis 11,12$)$ & 7.8 & $\operatorname{tr}$ & 11.6 \\
$\Delta 19: 0($ cis 9,10$)$ & 1.1 & - & 11.6 \\
Unidentified & 1.8 & - & - \\
\hline
\end{tabular}

$a$, not detected. 


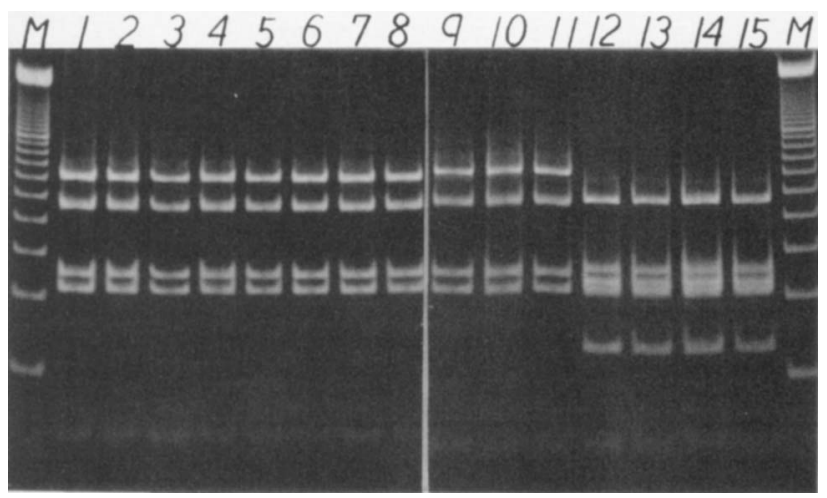

$B$

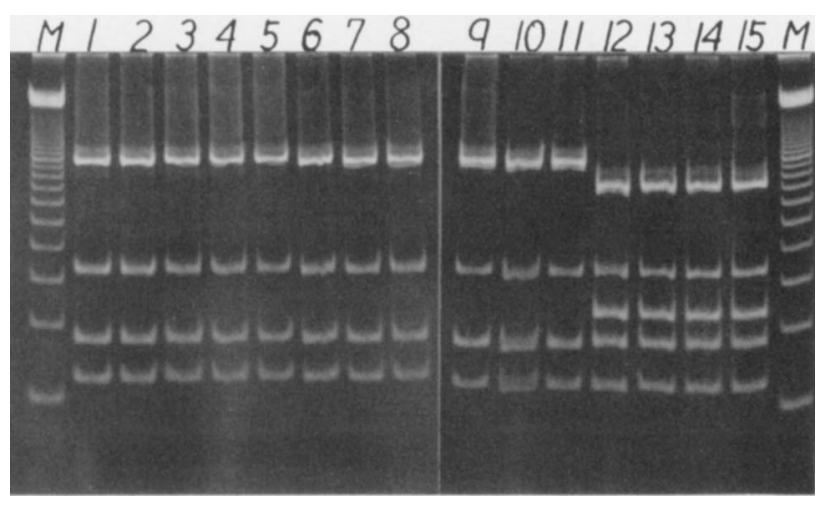

FIG. 2. PCR RFLP analysis of new isolates $\mathrm{X}-1^{\mathrm{T}}$ to $\mathrm{X}-11$ and $T$. halophilus IAM 1673, IAM $1676^{\mathrm{T}}$, IAM 1678, and IAM 1681 obtained by digestion of PCR products with restriction endonucleases $A l u \mathrm{I}(\mathrm{A})$ and $M b o \mathrm{I}(\mathrm{B})$. Lane $1, \mathrm{X}-1^{\mathrm{T}}$; lane 2, X-2; lane 3, X-3; lane 4, X-4; lane 5, X-5; lane 6, X-6; lane 7, X-7; lane $8, X-8$; lane 9, X-9; lane 10, X-10; lane 11, X-11; lane 12, IAM 1673; lane 13, IAM $1676^{\mathrm{T}}$; lane 14 , IAM 1678 ; lane 15 , IAM 1681; lane $\mathrm{M}$, size marker (100-bp ladder). parison of the DNA fragment patterns of all of the new isolates and four authentic $T$. halophilus strains (IAM 1673, IAM $1676^{\mathrm{T}}$, IAM 1678, and IAM 1681) revealed that the AluI and $M b o$ I fragment patterns of the two groups were clearly different. To investigate the phylogenetic relationships of the isolates further, 16S rDNAs amplified by PCR were subjected to a sequence analysis. Almost complete 16S rDNA sequences of representative strain $\mathrm{X}-1^{\mathrm{T}}$ and $T$. halophilus IAM $1676^{\mathrm{T}}$ were determined. A $T$. halophilus sequence has been described previously (4), but there were many ambiguous bases in this sequence. Therefore, we determined the 16S rDNA sequence of T. halophilus IAM $1676^{\mathrm{T}}$ to study the interspecies relationships of lactic acid bacteria, particularly the difference between our new isolates and $T$. halophilus. The 16S rDNA fragments used, excluding the PCR primer annealing regions, consisted of continuous nucleotide stretches from positions 28 to 1,525 (Escherichia coli numbering system) that were 1,452 to 1,540 bases long. Table 4 shows the evolutionary distances ( $K_{\text {nuc }}$ values) for $\mathrm{X}-1^{\mathrm{T}}$ and 14 lactic acid bacteria. The 16S rDNA sequence of $\mathrm{X}-1^{\mathrm{T}}$ was most similar (level of sequence similarity, 93.4\%) to the sequence of $T$. halophilus IAM $1676^{\mathbf{T}}$, but other reference strains exhibited low levels of similarity (less than 90\%). Figure 3 shows the phylogenetic position of new isolate $\mathrm{X}-1^{\mathrm{T}}$.

DNA-DNA hybridization. Table 5 shows the levels of DNADNA relatedness among the strains studied. DNA-DNA hybridization experiments performed with labeled DNAs from strains X-1 ${ }^{\mathrm{T}}, \mathrm{X}-2$, IAM $1676^{\mathrm{T}}$, and IAM 1678 revealed that the new isolates were closely related to each other but exhibited relatively low levels of hybridization (less than $50 \%$ ) with the four previously described strains of $T$. halophilus (IAM 1673, IAM $1676^{\mathbf{T}}$, IAM 1678, and IAM 1681).

\section{DISCUSSION}

The results of our phenotypic, chemotaxonomic, and phylogenetic analyses clearly indicate that strain $X-1^{\mathrm{T}}$ represents a new species of the genus Tetragenococcus. A total of 11 strains isolated from fermented squid liver sauce form a phenotypically homogeneous group that can be regarded as a single species. These organisms are gram-positive, non-spore-forming, nonmotile, tetrad-forming cocci. They are halophilic, fac-

TABLE 4. Evolutionary distance $\left(K_{\text {nuc }}\right)$ values for $16 \mathrm{~S}$ rDNAs of strain $\mathrm{X}-1^{\mathrm{T}}$, T. halophilus, and related organisms

\begin{tabular}{|c|c|c|c|c|c|c|c|c|c|c|c|c|c|c|}
\hline \multirow[b]{2}{*}{ Organism } & \multicolumn{14}{|c|}{$K_{\text {nuc }}$ value with: } \\
\hline & 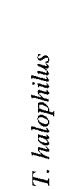 & $\stackrel{\vec{x}}{x}$ & 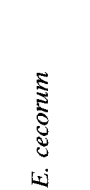 & 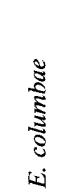 & 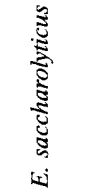 & 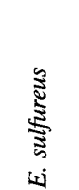 & 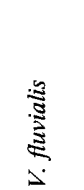 & 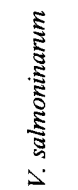 & 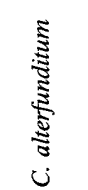 & 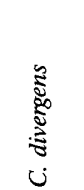 & 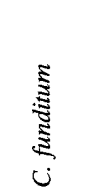 & 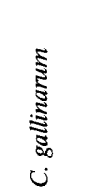 & 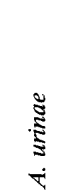 & 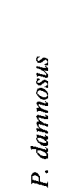 \\
\hline $\mathrm{X}-1^{\mathrm{T}}$ & 0.052 & & & & & & & & & & & & & \\
\hline E. cecorum & 0.087 & 0.093 & & & & & & & & & & & & \\
\hline E. columbae & 0.096 & 0.102 & 0.027 & & & & & & & & & & & \\
\hline E. saccharolyticus & 0.074 & 0.081 & 0.041 & 0.046 & & & & & & & & & & \\
\hline E. sulfureus & 0.072 & 0.084 & 0.047 & 0.058 & 0.030 & & & & & & & & & \\
\hline V. fluvialis & 0.109 & 0.106 & 0.070 & 0.081 & 0.062 & 0.059 & & & & & & & & \\
\hline V. salmoninarum & 0.105 & 0.116 & 0.083 & 0.090 & 0.070 & 0.070 & 0.053 & & & & & & & \\
\hline C. alterfunditum & 0.107 & 0.110 & 0.077 & 0.084 & 0.069 & 0.071 & 0.081 & 0.079 & & & & & & \\
\hline C. divergens & 0.106 & 0.111 & 0.073 & 0.077 & 0.068 & 0.059 & 0.079 & 0.065 & 0.044 & & & & & \\
\hline C. funditum & 0.100 & 0.113 & 0.083 & 0.094 & 0.073 & 0.065 & 0.081 & 0.074 & 0.035 & 0.045 & & & & \\
\hline C. gallinarum & 0.111 & 0.122 & 0.081 & 0.082 & 0.079 & 0.072 & 0.091 & 0.075 & 0.047 & 0.033 & 0.050 & & & \\
\hline A. urinae & 0.129 & 0.135 & 0.112 & 0.108 & 0.110 & 0.107 & 0.107 & 0.111 & 0.109 & 0.096 & 0.103 & 0.105 & & \\
\hline P. damnosus & 0.148 & 0.152 & 0.111 & 0.108 & 0.113 & 0.118 & 0.113 & 0.117 & 0.104 & 0.104 & 0.107 & 0.107 & 0.135 & \\
\hline L. lactis & 0.169 & 0.165 & 0.138 & 0.133 & 0.138 & 0.148 & 0.154 & 0.150 & 0.140 & 0.155 & 0.148 & 0.153 & 0.169 & 0.157 \\
\hline
\end{tabular}




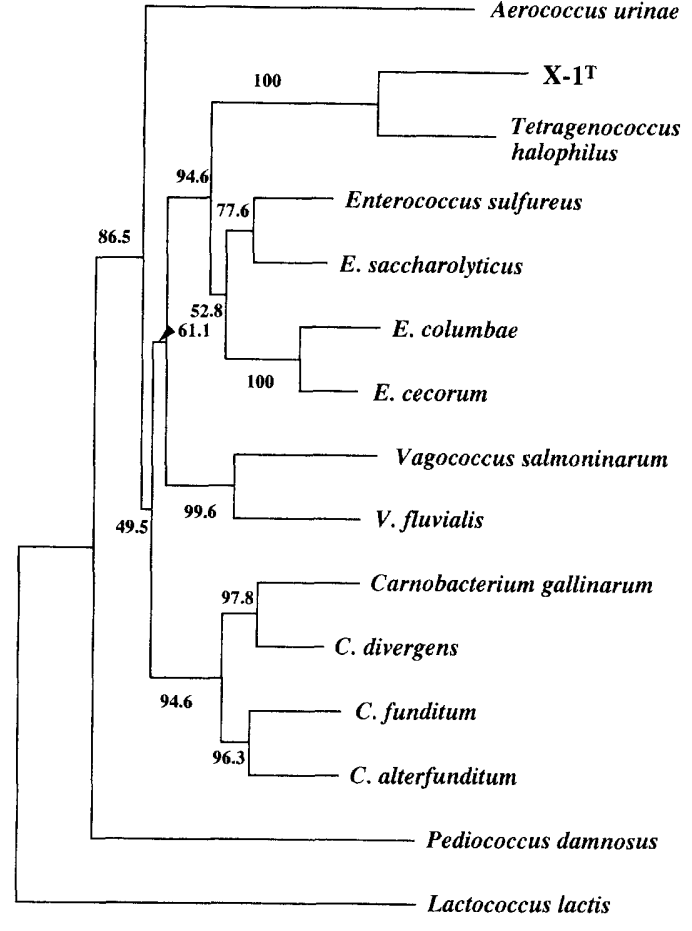

FIG. 3. Phylogenetic tree based on $16 \mathrm{~S}$ rDNA sequences of new isolate $\mathrm{X}-1^{\mathrm{T}}$ and selected lactic acid-producing bacteria. The numbers at the nodes indicate the percentages of occurrence in 1,000 bootstrapped trees. Only values greater than $40 \%$ are shown. Bar $=0.0099 K_{\text {nuc }}$.

ultatively anaerobic, lactic acid-producing bacteria whose fermentation type is homogeneous and whose optical form of lactic acid is $\mathrm{L}-(+)$. They are also catalase negative; nitrate is not reduced, arginine is not hydrolyzed, and the organisms tolerate a high $\mathrm{NaCl}$ concentration $(18 \%)$ and have genomic DNA $\mathrm{G}+\mathrm{C}$ contents of ca. $36 \mathrm{~mol} \%$, values which are similar to the $\mathrm{G}+\mathrm{C}$ contents of $T$. halophilus and some previously described Pediococcus species $(6,21)$. The cell wall peptide compositions also were the same as those of $T$. halophilus (21). On the basis of these characteristics, the new isolates should be considered members of the genus Tetragenococcus $(6,21)$.

Phenotypically, the new isolates can be distinguished from $T$. halophilus by their lack of fermentation of L-arabinose, sucrose, and lactose and by their production of histamine. However, these phenotypic differences are not enough to differentiate our isolates from $T$. halophilus, because some diversity in

TABLE 5. Levels of DNA-DNA reassociation between new isolates and T. halophilus strains

\begin{tabular}{|c|c|c|c|c|}
\hline \multirow{2}{*}{ Strain } & \multicolumn{4}{|c|}{ \% Relatedness to labeled DNA from: } \\
\hline & $\mathrm{X}-1^{\mathrm{T}}$ & $X-2$ & IAM $1676^{T}$ & IAM 1678 \\
\hline$X-1^{\mathrm{T}}$ & 100 & 92 & 47 & 36 \\
\hline $\mathrm{X}-2$ & 97 & 100 & 45 & $\mathrm{ND}^{a}$ \\
\hline \multicolumn{5}{|c|}{ T. halophilus strains } \\
\hline IAM 1673 & ND & 23 & 79 & ND \\
\hline IAM $1676^{\Gamma}$ & 49 & 35 & 100 & ND \\
\hline IAM 1678 & 21 & 29 & 92 & 100 \\
\hline IAM 1681 & $\mathrm{ND}$ & 15 & 100 & ND \\
\hline
\end{tabular}

${ }^{a}$ ND, not determined. sugar utilization patterns has previously been reported within the population of $T$. halophilus $(11,19)$.

On the basis of the results of the fatty acid composition analysis, the new isolates can be distinguished from $T$. halophilus by their lack of a large amount of $\Delta 19($ cis 9,10$)$, which is a positional isomer of lactobacillic acid, $\Delta 19($ cis 11,12$)$. The presence of $\Delta 19($ cis 9,10$)$ in $T$. halophilus has not been described previously (18). The presence of this fatty acid originates from the fact that we used GYP medium which was supplemented with Tween 80 for growth, which probably induced the organisms to produce $\Delta 19($ cis 9,10$)$ from oleic acid.

The most reliable method for determining species affiliations is $16 \mathrm{~S} \mathrm{rDNA}$ sequence analysis, which clearly differentiates the new isolates from $T$. halophilus. Using the results of the genetic analysis performed by comparing $16 \mathrm{~S}$ rDNA RFLP patterns, we confirmed that the new isolates are genetically different from T. halophilus. Moreover, the results of the phylogenetic analysis based on 16S rDNA sequences supported the conclusions described above and further clarified the taxonomic and phylogenetic positions of the new isolates among the members of genus Tetragenococcus and related lactic acid bacteria. The phylogenetic tree in Fig. 3 shows that strain $X-1^{\mathrm{T}}$ forms a cluster with $T$. halophilus IAM $1676^{\mathrm{T}}$, but the evolutionary distance is clearly great enough to separate these strains as members of two different species. This opinion is strongly supported by the DNA-DNA hybridization results, which satisfy the recommendations of the Ad Hoc Committee on Reconciliation of Approaches to Bacterial Systematics (20).

On the basis of the phenotypic, genotypic, and phylogenetic data, it is logical to conclude that the new isolates which we studied should be classified as members of a new species of the genus Tetragenococcus. We propose the name T. muriaticus for these organisms.

Description of Tetragenococcus muriaticus sp. nov. Tetragenococcus muriaticus (mu.ri.a' ti.cus. L. adj. muriaticus, briny, pickled). Cells are cocci ( 0.5 to $0.8 \mu \mathrm{m}$ in diameter) and form tetrads or pairs. Colonies are white, convex, smooth, and up to $1.5 \mathrm{~mm}$ in diameter. Cells are gram positive. Nonmotile. Growth occurs at $\mathrm{NaCl}$ concentrations of 1 to $25 \%$; the $\mathrm{NaCl}$ concentration for best growth is 7 to $10 \%$. No growth occurs in the absence of $\mathrm{NaCl}$. Growth occurs at 15 to $40^{\circ} \mathrm{C}$ but not at $45^{\circ} \mathrm{C}$. The optimal growth temperature is 25 to $30^{\circ} \mathrm{C}$. Growth occurs at pH 5.0 to 9.6, and the optimal pH is 7.5 to 8.0 . Facultatively anaerobic. Catalase and oxidase negative. Homofermentative, producing L-lactic acid. Arginine is not hydrolyzed. Nitrate is not reduced to nitrite. Histamine is produced. Acid is produced from D-ribose, fructose, D-mannose, trehalose, and mannitol. Acid is not produced from L-arabinose, D-xylose, lactose, sucrose, raffinose, sorbitol, gluconate, dextrin, and starch. The cell wall peptides contain Lys-D-Asp. The $\mathrm{G}+\mathrm{C}$ content of the DNA is $36.5 \mathrm{~mol} \%$ (as determined by high-performance liquid chromatography). Isolated from fermented squid liver sauce. The type strain is strain X-1 (= JCM 10006).

\section{REFERENCES}

1. American Oil Chemists' Society. 1990. Official methods and recommended practices, 4th ed. American Oil Chemists' Society, Chicago, Ill.

2. Anonymous. 1994. Validation of the publication of new names and new combinations previously effectively published outside the IJSB. List no. 49. Int. J. Syst. Bacteriol. 44:370-371.

3. Bligh, E. G., and W. J. Dyer. 1959. A rapid method of total lipid extraction and purification. Can. J. Biochem. Physiol. 37:911-917.

4. Collins, M. D., A. M. Williams, and S. Wallbanks. 1990. The phylogeny of Aerococcus and Pediococcus as determined by $16 \mathrm{~S}$ rRNA sequence analysis: description of Tetragenococcus gen. nov. FEMS Microbiol. Lett. 70:255-262.

5. Ezaki, T., Y. Hashimoto, and E. Yabuuchi. 1989. Fluorometric deoxyribonucleic acid-deoxyribonucleic acid hybridization in microdilution wells as an alternative to membrane filter hybridization in which radioisotopes are used 
to determine genetic relatedness among bacterial strains. Int. J. Syst. Bacteriol. 39:224-229.

6. Garvie, E. I. 1986 Genus Pediococcus Claussen 1903, 68 AL p. 1075-1079. In P. H. A. Sneath, N. S. Mair, M. E. Sharpe, and J. G. Holt (ed.), Bergey's manual of systematic bacteriology, vol. 2. The Williams \& Wilkins Co. Baltimore, Md.

7. Ito, H., R. S. Hadioetomo, S. Nikkuni, and N. Okada. 1985. Studies on lactic acid bacteria in fish sauces (part 1). Chemical composition and microflora of fish sauce. Rep. Natl. Food Res. Inst. 47:23-30.

8. Ito, H., R. S. Hadioetomo, S. Nikkuni, and N. Okada. 1985. Studies on lactic acid bacteria in fish sauces (part 2). Identification of salt-tolerance and acid-producing bacteria from fish sauces. Rep. Natl. Food Res. Inst. 47:3140.

9. Kimura, M. 1980. A simple method for estimating evolutionary rates of base substitution through comparative studies of nucleotide sequences. J. Mol. Biol. 16:111-120.

10. Kozaki, M., S. Okada, and T. Uchimura. 1992. Laboratory manual for lactic acid bacteria. Asakura-shoten, Tokyo, Japan. (In Japanese.)

11. Röling, W. F. M., and H. W. van Verseveld. 1996. Characterization of Tetragenococcus halophila populations in Indonesian soy mash (Kecap) fermentation. Appl. Environ. Microbiol. 62:1203-1207.

12. Saitou, N., and M. Nei. 1987. The neighbor-joining method: a new method for reconstructing phylogenetic trees. Mol. Biol. Evol. 4:406-425.

13. Sambrook, J., E. F. Fritsch, and T. Maniatis. 1989. Molecular cloning: a laboratory manual, 2nd ed. Cold Spring Harbor Laboratory, Cold Spring Harbor, N.Y.
14. Sato, T., T. Fujii, M. Masuda, and M. Okuzumi. 1994. Changes of numbers of histamine-metabolic bacteria and histamine content during storage of common mackerel. Fish. Sci. 60:299-302.

15. Suzuki, T., and K. Yamasato. 1994. Phylogeny of spore-forming lactic acid bacteria based on 16S rRNA gene sequences. FEMS Microbiol. Lett. 115: 13-18.

16. Tamaoka, J., and K. Komagata. 1984. Determination of DNA base composition by reversed-phase high performance liquid chromatography. FEMS Microbiol. Lett. 25:125-128.

17. Thompson, J. D., D. G. Higgins, and T. J. Gibson. 1994. Clustal W: improving the sensitivity of progressive multiple sequence alignment through sequence weighting, positions-specific gap penalties and weight matrix choice. Nucleic Acids Res. 22:4673-4680.

18. Uchida, K., and K. Mogi. 1972. Cellular fatty acid spectra of Pediococcus species in relation to their taxonomy. J. Gen. Appl. Microbiol. 18:109-129.

19. Uchida, K. 1989. Multiplicity in soy pediococci carbohydrate fermentation and its application for analysis of their flora. J. Gen. Appl. Microbiol. 28: 215-225.

20. Wayne, L. G., D. J. Brenner, R. R. Colwell, P. A. D. Grimont, O. Kandler, M. I. Krichevsky, L. H. Moore, W. E. C. Moore, R. G. E. Murray, E Stackebrandt, M. P. Starr, and H. G. Trüper. 1987. Report of the Ad Hoc Committee on Reconciliation of Approaches Bacterial Systematics. Int. J. Syst. Bacteriol. 37:463-464.

21. Weiss, N. 1992. The genera Pediococcus and Aerococcus, p. 1503-1507. In A Balows, H. G. Trüper, M. Dworkin, W. Harder, and K. H. Schleifer (ed.), The prokaryotes, 2nd ed., vol. 2. Springer Verlag, New York, N.Y. 